\title{
Press discourses on Roma in the UK, Finland and Hungary
}

Nira Yuval-Davis ${ }^{a}$, Viktor Varjú ${ }^{b}$, Miika Tervonen ${ }^{c}$, Jamie Hakim ${ }^{d}$ and Mastoureh Fathi $^{\mathrm{e}}$

aSchool of Social Sciences, University of East London, London, UK; blnstitute of Regional Studies, MTA KRTK (CERS of HAS), Pécs, Hungary; cDepartment of Social Research, University of Helsinki, Helsinki, Finland; dDepartment of Media Studies, University of East Anglia, Norwich, UK; eFaculty of Health and Social Sciences, Bournemouth University, Bournemouth, UK

\section{Abstract}

This article analyses the political and media discourses on Roma in Hungary, Finland and the UK, in relation to both the local Roma in these countries as well as those who migrated from and to these countries following the fall of communism in Central and Eastern Europe. To do so the authors have analysed left of centre and right of centre major newspapers in these three countries, focusing on specific case studies which were foci of public debates during the last two decades. In addition they examined a common case study in 2013 ('Blond Maria') that was discussed throughout Europe. The article examines the constructions of Roma, both local and migrant, in each newspaper and how these have changed over the period studied in this research. The conclusion of the article examines the multi-layered processes of social and political borderings which dominate discourses on Roma, 'indigenous' and migrant, and the extent to which they constitute a coherent 'European' construction of 'the Roma'.

Key words: Roma, Hungary, Finland, UK, Bordering, press analysis

\section{Introduction}

In much of the literature on racism, colour and religion are constructed as the most important signifiers of racialization. And yet it is the Roma people who have emerged repeatedly in various studies as the most stigmatized and racialized grouping in Europe (Aluas and Matei 1998; Levine-Rasky et al. 2014). Following the expansion of the EU in 2004 and the inclusion of Romania and Bulgaria in 2007, the diverse Roma groups can be seen as forming the largest 
ethnic minority within EU boundaries (EERC 2010). ${ }^{1}$ This article analyses the political and media discourses on both migrant and local Roma in Hungary, Finland and the UK, as illustrative of the range of histories and policies to which Roma people have been subjected to in different parts of Europe.

As elsewhere in Europe, these countries have long-standing ethnic groupings that contemporarily come under the umbrella name of Roma. ${ }^{2}$ All these groups have underwent histories of persecution and racialization, as well as post-war policies ranging from forced assimilation and multicultural recognition. There are an estimated 650,000 Roma (Bernát 2014) living in Hungary who are diverse, but usually seen as composed of three main communities. The largest is the Hungarian-speaking Romungro, while the Vlach (Oláh in Hungarian) speak Hungarian and Lovari, and the Beás/Boyash Hungarian and Romanian (Kemény 2000). ${ }^{3}$ In Finland, the Kaale Roma are conventionally estimated to number around 10,000 individuals, with an additional 3-4,000 living in Sweden after migrating in the 1960s-80s (The Ministry of Social Affairs and Health 2009). In the UK there are around 4-500,000 Roma (Brown et al. 2013:7). It is a heterogeneous population with different cultural identities and lifestyles. The major older groupings are the Gypsies (British Roma), Irish Travellers, the 'New Age Travellers'.

In Finland and the UK, there has been a migration from Central and East European Roma communities since the fall of the Soviet Union, with arrivals of first asylum seekers, and later EU migrants. Despite the tiny size of the migrant groups in Finland and in the UK, their arrival has reactivated anti-Gypsyist phobia of racialised 'nomads' ${ }^{4}$, and produced at times full-fledged moral panics. In the UK, the immigration of Irish Travellers has also been a debated issue. Meanwhile, in Hungary, the debates have dealt rather with the emigration of Roma, with conflicting explanatory narratives pointing either to problems within the Roma communities, within the Hungarian society as a whole or to external actors such as the EU.

This article examines press discourses both in relation to the 'indigenous' Roma and those who migrated from and to these countries following the fall of communism in Central and Eastern Europe. In this, the article contributes to a growing body of literature on the situation of Roma in contemporary Europe (eg. Grill 2012; Picker 2013; Sigona and Trehan 2009; 
Ryder, Cemlyn and Acton 2014; Vitale and Legros 2011) as well as specific media and press studies (e.g. Bernáth and Messing 2013; Balch and Balanova 2014; Clark and Campbell 2000). The main focus of our analysis is on the ways in which these press discourses on Roma have been used to construct bordering processes to differentiate between those who belong and those who do not.

\section{Methodology}

The analysis in this article is embedded in the theoretical and methodological framework developed by the Work Package 9 team of the EUBorderscapes project on situated intersectional everyday bordering (Yuval-Davis 2014; YuvalDavis, Wemyss and Cassidy 2017, forthcoming). Our point of departure is a shared understanding of borders - social, political, geographical - not as territorial, static, naturalized, social and political 'lines', but rather as continuous, dynamic and contested processes (eg. Brambilla 2015; Rajaram and Grundy-Warr 2007). We further argue, that these bordering processes need to be understood as grounded in differing social positionings. We have thus sought to combine the methodological tools of what Lesley McCall (2005) calls inter-categorical and intra-categorical analyses, by exploring the shifting and contested constructions of the categories of analysis across space, time and normative political approaches.

We chose to apply these types of analyses to the press coverage of Roma/bordering issues because the mass media continues to be a key site in which forms of knowledge struggle to achieve the status of 'common sense'(Gramsci 1971). As Emil Edenborg (2016) argues, the media, by controlling and constraining visibility of particular groupings in particular ways, plays a crucial role in the construction, reproduction and contestation of borders and boundaries in specific political projects of belonging.

We began the analysis with a preliminary examination of the press in the three countries, focusing on several generic analytical categories reflecting the construction of Roma in the studied newspapers. These were: discourses, categories and stereotypes used to describe and/or racialize the Roma; the extent to which all Roma were homogenized or differentiated into subcategories; and the ways in which they were positioned vis a vis other ethnic 
minorities as well as the hegemonic majority in the country. We were further interested in whose voices were heard in the press discourses, and especially the extent to which Roma voices were included, if at all.

We analysed discourses on Roma in one left of centre and one right of centre newspaper in each country, at particular moments of time during the last two decades. In Hungary, the analysis focused on the left of centre Népszabadság (NSZ), and the right of centre Magyar Nemzet (MN), both daily newspapers. In Finland, we analysed coverage in the largest circulation newspaper Helsingin Sanomat (HS) and the evening tabloid IItalehti (IL). ${ }^{5}$ In the UK the newspapers selected were The Guardian, a left of centre daily broadsheet and the right of centre The Sun, the largest circulation daily tabloid in Britain.

In each country, we measured the amount of yearly coverage of Roma issues in the left of centre newspapers to identify 'peaks' of interest. The stories that produced these peaks became the case studies in this article. We also chose one common case study, 'Blond Maria', the girl seized by the police in Greece in 2013 from Roma people on suspicion of kidnapping.

In Hungary, using the Parliament Library database, we found a total of 2719 news items on Roma groups in NSZ. The items given the most coverage were: (1) a housing issue relating to 13 Roma families in Székesfehérvár (in $1997-98)^{6} ;(2)$ a news story relating to a number of Roma families' migration from Zámoly and their refugee claims in Strasbourg $(2001)^{7} ;$; 3 coverage of increasing racism and attacks against Roma $(2009)^{8}$.

In Finland we identified 965 relevant articles in HS. The three identified peaks related to: (1) the arrival of Roma asylum seekers from Slovakia, Poland, Latvia and Kosovo (1999-2000) ${ }^{9}$; (2) debates on Finnish Roma culture, initiated by Roma activists and artists $(2007)^{10} ;(3)$ debates on the circular EU-migration of Roma from Romania and Bulgaria, and on a legislative initiative to criminalize begging (2010-2012) ${ }^{11}$.

In the UK we identified more than 3000 articles in The Guardian ${ }^{12}$. The identified peaks were: (1) the increase in Czech and Slovak Roma migration to Dover in $1997^{13}$; (2) the Conservative Party's use of Roma issues in their 2005 election campaign which corresponded to a public campaign against 'illegal' 
Roma squatters initiated by The Sun ${ }^{14}$; (3) the highly publicized eviction of a Roma community from the land they owned in Dale Farm, Essex in $2011^{15}$

Exceptionally we also added a fourth UK case study focused on the remarks that ex-Home Secretary David Blunkett made about the alleged tension that Roma migrants were causing in Sheffield in $2013^{16}$, as this happened around the same time of the debate on the issue of 'Blond Maria ${ }^{17}$.

In the following, we report our main findings regarding the constructions of Roma, and how these have changed over the studied period. In the concluding discussion we examine the multi-layered processes of social and political borderings between the hegemonic majority and Roma, 'indigenous' and migrant, paying also attention to the extent to which we can observe a 'European' construction of 'the Roma'.

\section{The Hungarian case study}

Although most of the Roma in Hungary belong to three main linguistic and cultural groups, the press discourse homogenizes and racializes them into a single subject. While stereotypes and discourses on Roma have been changing over the period we analyzed, Roma remained a homogenous category in the press coverage. The only significant difference made in the press between the Roma is either specifying where they live in Hungary or from which countries they have migrated from and to. ${ }^{18}$

In 1997-98 the main Roma-related issue in the press was the so-called Székesfehérvár story. The local government of Székesfehérvár decided to demolish a run-down blockhouse where Roma were living and move them into container houses, then into cheap houses in the surrounding area of the city. This policy encountered fierce opposition from a Roma civil-rights organisation and people living in the local neighbourhood. In the eventual solution, the mayor agreed to settle the Roma in rented flats in the city rather than container houses. Meanwhile, the local people prevented the settlement of Roma families in the neighbouring villages.

The story of Zámoly ${ }^{19}$, which also began in 1997, became a hot issue in the press in 2000. Roma families were forced to leave their rented accommodation, which had been condemned by the local government as a 
result of storm damage. They were first settled into public housing, then moved into other settlements and finally, several years later, the National Roma Government ${ }^{20}$ built wooden houses for them in Zámoly. However, the evacuated Roma families did not want to move into these houses, because of their fear of racism from the local population. Finally, led by a former local Roma representative, the families migrated to Strasbourg and claimed political asylum.

Both of these cases focus on the issue of adequate social housing as well as the racialized fear that local people have of the Roma moving into their neighbourhoods. In both cases the main public debates were around who was responsible for the issue, what caused it and who should provide the solution. While $M N$ blamed the Roma in these stories, NSZ focused on the solution. This difference can be seen in the titles of the coverage. ${ }^{21}$ The rhetoric of discrimination - with political context - was strong in the Zámoly case in 2001, especially in NSZ, as a critique of the Orbán government's Roma policy.

The analysis of the press during the peak in Roma coverage in 1998-99 reveals a contestation between a construction of Roma issues as part of 'standard' social problems such as quality of life, housing problems, segregation and discrimination and a specific discourse focusing on 'minority rights' for Roma. However, in relation to the latter, it was often argued that the Roma are more privileged than other Hungarian 'official' minorities, or even the hegemonic majority. This argument was iterated particularly in relation to the Roma representation in the Hungarian Parliament, with conflicting arguments. In the NSZ, the ombudsman of minority rights (16 February 2009) voiced concern over everyday racism towards the Roma. A week later (25 February 2009) MN made an interview with the ombudsman, challenging his position: 'Does defence of ethnic rights mean that only minorities have rights? Does the majority of the society have ethnic rights?'

The 'Anti-Ghetto Committee, ${ }^{22}$, established in 1989, is usually referred to as the starting point of Roma self-organisation. During the following decade, a number of Roma politicians appearing in the public media faced accusations that this was mainly a strategy to advance their political careers. The 'careerbuilding' stereotype was often cited, especially by the right wing newspaper in the Zámoly migration (and the former Székesfehérvár housing) $\operatorname{cases}^{23}$, in 
relation to the families' leader, József Krasznai. He acted as a Roma representative also in the Székesfehérvár housing issue. As the story became a political issue on a national level, several other Roma representatives became involved and were subsequetly also vilified for it in the $M N$.

During the 2000s, the appearance of Roma people, leaders and politicians decreased significantly in the press. At the same time, there were routine referencing of Roma organisations and a number of former Roma representatives in mainstream politics. However, by the end of 2000s, discourses on the Roma had underwent a significant change. While there was a strengthening of radical right wing and incidences of lethal violence against the Roma, the media representation of the Roma became more heavily tinted by racism and criminalization of the Roma ${ }^{24}$. The rhetoric of the two newspapers, however, were quite divergent. While NSZ continued to problematize antiGypsyist racism and violence, $M N$ constructed a racialized boundary of belonging between Roma and Non Roma people in Hungary:

'There are two types of society in Hungary today. People in the first know the rules of living together... The second society skipped the socialization, persons in it live on their instincts...most of the members of the second society are Roma' (MN, February 2, 2009).

Most of the press coverage on Roma relates to local Roma or, at times, their emigration from Hungary to France, Canada and the UK. ${ }^{25}$ However, there are some articles that relate to Roma also in other Central and East European countries, discussing their migration to the West as a result of an all-European racism against Roma. ${ }^{26}$

However, the case of 'Blond Maria' did not fall into this category. It received little press in Hungary and when it was covered, the people involved were described as Bulgarian as opposed to Roma or Bulgarian Roma. ${ }^{27}$

Overall, the discourse on Roma in the Hungarian press seems to be directly connected to wider public debates and party- and governmental politics. The stories about the Roma are often used to highlight the failed general politics and/or Roma policies of the political party the newspaper opposes, whether on the right or left of the political spectrum (although, as a rule, $N S Z$ 's discourses were more moderate than those of $M N){ }^{28}$ 
Everyday Romani people's voices are under-represented in the analyzed articles. Most of the time they were represented by Roma local government officials, human rights organizations and the minority ombudsman. There is a clear decline in the representation of Roma voices in the press. While in 1998, the voice of at least one Roma is present in about half of the analysed articles, in 2009, it had decreased to about a quarter.

Roma groups are constructed, especially but not exclusively in the left wing NSZ, as both part and outside of Hungarian national society. Their emigration is viewed as an outcome of this racialized ambiguous belonging, both by the local Roma and by the hegemonic Hungarian collectivity. While NSZ is more sympathetic to the plight of the Roma, and $M N$ tends to discredit their grievances, this perspective is shared by the two newspapers.

\section{The Finnish case study}

Throughout the analysed Finnish material, a consistent distinction is made between the national Roma minority and the Roma migrants from Eastern Europe. The discourses on the former connect to a long history of problematizing the Finnish Roma as a domestic 'other', but also to the increasingly sensitive rhetoric of modern minority politics (Tervonen 2012). There are thus evident tensions and shifts in what can and should be written in relation to the Finnish Roma, as exemplified by the rapid replacement of the ethnonym mustalainen ('Gypsy') by romani ('Roma') in the 1990 s. $^{29}$ During the public debates Finnish Roma culture in 2007, there is also a discernible element of cautiousness in most of the writing in the $I L$ and the $H S .{ }^{30}$

Meanwhile, debates on the migrant Roma are connected to a politicization of humanitarian and low-skilled immigration, and have clearer continuities with old anti-gypsyist and racial discourses. A narrative of borders threatened by unwanted newcomers is particularly clear in relation to the mostly Slovakian asylum seekers who arrived in 1999-2000. Despite a recognition of discrimination and human rights violations ${ }^{31}$, they are nevertheless not considered as 'real' asylum seekers ${ }^{32}$. Both papers specify the Roma ethnicity of the migrants from the start, with $I L$ evoking exoticizing stereotypes of dark-eyed wanderers. ${ }^{33}$ In the substance of the editorials and 
op-eds, there is no significant difference between the newspapers. ${ }^{34} \mathrm{~A}$ hierarchy is built between 'real' asylum seekers and the 'uncontrollable torrent' of arriving Roma, and the authorities are presented as 'unable to manage the situation' because of overly liberal asylum laws. ${ }^{35}$ The migrants are pointed to as an argument for more restrictive asylum policy. Both $I L$ and $H S$ voice support for the authorities' urge for stricter legislation. ${ }^{36}$ When a temporary visa requirement on Slovakian citizens was imposed, this was termed 'inevitable' by both papers ${ }^{37}$, and greeted by the $I L$ as a 'solution' to 'the problem of Roma arriving to the country'. ${ }^{38}$

In comparison, the debate on the EU migrants and the begging ban in 2010-2012 brings to the surface more political contestation and critical discussions. There is a division into 'pro' and 'con' editorials and columns, and corresponding conceptualizations of the Roma migrants as either 'victims' ${ }^{39}$ or 'criminals'. ${ }^{40}$ The 'victim'-perspective, representing the Roma migrants as structurally discriminated against, recurs particularly in the $H S^{41}$, and occasionally in the $I L{ }^{42}$ The EU is implicated; for example, an op-ed published in 2010 argues that "the Roma who flee from a vicious cycle of poverty are the flipside of the European integration process - an image of European poverty painful to look at" ${ }^{43}$ However, the conclusions drawn from the victimperspective vary, with the idea that "they should be helped in their home countries" used to argue against inclusive policies in Finland. ${ }^{44}$

From 2012 onwards, the discourse on the 'Roma beggar' seems to become less ethnicized and lose some of its urgency. The volume of writing in $I L$ and $H S$ decreases; in a number of articles the situation of EU migrants is written of as part of wider migration-related policy issues, concerning e.g. access to health care ${ }^{45}$, homelessness ${ }^{46}$; or politics of free movement in Europe. $^{47}$

There are no direct references to 'race' (rotu) in the studied texts, and little explicit references to anti-Roma stereotypes. The distinction between domestic and foreign Roma means that there is no straightforward lumping together of all Roma into one racialized group. However, within the main groups written about, there is little internal differentiation. Particularly the asylum seekers are written about as a singular homogenous group, constituting a 'Roma problem'. ${ }^{48}$ Moreover, particularly in $I L$, 'neutral' news 
items are frequently coupled with headlines, images and captions which play more directly with racialized stereotypes. The Roma migrants are also implicitly or explicitly associated with crime in almost a quarter of the $I L$ coverage studied. With no ethno-specific crime statistics, such implicit association can be created for example by collapsing the categories 'Roma' and 'Romanian', and presenting crime statistics on the latter to delegitimize the former ${ }^{49}$ Meanwhile, unsubstantiated references to human smugglers and Mafioso organizers of begging rings appear also in the $H S^{50}$

The most direct racial references occur in $I L$ related to 'Blond Maria'. Between $18^{\text {th }}$ and $26^{\text {th }}$ October, a series of articles created a moral distinction between dark-skinned child kidnappers on the one hand, and police, child care agents and Nordic parents of missing children on the other. IL's piece on the $18^{\text {th }}$ October ('Has she been kidnapped from Scandinavia? A blond girl found in a Roma camp') cites Greek police and portrays Maria's host parents as kidnappers and/or human traffickers. ${ }^{51}$

HS was more cautious and started publishing more on the case only after evidence started mounting against the initial narrative of child-snatching Roma. Still, also in HS there was a persistent ethnic framing of the reporting, with the Romani ethnicity of the host parents/kidnapping suspects mentioned in every article on the issue. ${ }^{52}$

Overall, there is a consistent difference with regards to Finnish Roma and Eastern European Roma migrants in $H S$ and IL. The Finnish Roma are given a relatively more positive and diffuse coverage. While NGO representatives and 'ordinary' Finnish Roma are frequently given voice, Roma migrants are seen and discussed but seldom heard. The discourse is dominated by authorities, with human rights NGOs as a countervoice.

IL and HS differ particularly in their approach to the migrant Roma, with Iltalehti more prone to associate the migrants with crime and to play on racialized stereotypes in its use of images and headlines. Still, both newspapers seem to be characterised by a tendency towards surface-level 'neutrality' in avoiding expressly racialized language; while oscillating between 'victim' and 'criminal' perspectives; and relying heavily on the authorities as a source of information. To the extent that wider immigration dilemmas are discussed via 
the case of the Roma migrants, then, the discoursive 'bordering out' follows in the Finnish case a distinctively governmental logic. ${ }^{53}$

\section{The UK case study}

The major finding from the UK data is the way in which different Roma groups are homogenized in order to function as a sign onto which anxieties around perceived threats to the law abiding 'British way of life' are drawn, whether in terms of anti-nomadism or in terms of the perceived threat of the European Union to the UK's sovereignty and territorial integrity. This projection is achieved through the deployment of a multiplicity of discourses such as welfare, planning policies, cultural traditions, racial constructions and human rights. These discourses change emphasis in relation to different case studies but all relate in some way to an EU policy being introduced to the UK. The overall effect is the 'othering' of these different Roma groups.

In 1997, the major discursive framework used to make sense of the recently arrived Roma in Dover is that of welfare. This is achieved through the persistent use of three related discursive figures: the gypsy beggar, the welfare scrounger and the bogus asylum seeker. ${ }^{54}$ The Sun constructs these figures in its own voice whereas The Guardian critiques The Sun and other right wing newspapers for doing so as part of its coverage. ${ }^{55}$ The policy background at the root of the anxieties being projected onto the Roma in this news story, is the Dublin Convention's attempt to standardize asylum processes across the EU.

The Sun uses the terms Czech, East European ${ }^{56}$ and Gypsy ${ }^{57}$ interchangeably with homogenizing effect. The Guardian's coverage constructs a pro-migration, anti-racist reader/self. ${ }^{58}$ The 'other' is the sympathetically portrayed persecuted Roma. This othering is softened somewhat by the inclusion of quotes from Czech Roma teenagers. ${ }^{59}$ These quotes, however, often reinforce racial stereotypes ${ }^{60}$. The self in The Sun is the hard working taxpayer who is opposed to the 'chancers' and 'con-merchant' Gipsies [sic] who are falsely claiming asylum in order not to work but to scrounge off the welfare state. In a Sun political cartoon an alien representing Czech and Slovak Gipsies (sic) lands at the foot of the white cliffs of Dover asking "Take me to your... benefits office". ${ }^{61}$ 
In 2005 the press discourse focuses on the legality of the traveller's way of life. Issues of public spending remain significant though are secondary to the legal questions raised. The policy background to this story is the incorporation of the European Convention on Human Rights into British law. Both the Conservative campaign and The Sun accuse the travellers of abusing the new legislation. ${ }^{62}$ The Guardian uses its principles in the traveller's defence. ${ }^{63}$

The Roma in this story are homogenized as an "invasion"64 or a "plague" for example. ${ }^{65}$ At the same time an important distinction is made between the 'real' 'good' Roma, living in authorised sites and 'fake' nomadic travellers. ${ }^{66}$ Exceptionally, the settled communities are aligned with the British self which, in The Sun, is described in various places as "law-abiding" 67 "hard working citizens" ${ }^{\prime 68}$, "peaceful" ${ }^{\prime 9}$ and as "tax-payers". ${ }^{70}$ There are no 'good' Roma in The Sun's coverage of the other stories. The 'bad' Roma other is constructed as privileged in comparison to the hard-working British tax-paying citizen, exploiting as well as breaking the law ${ }^{71}$, benefiting from state services that 'ordinary' citizens are not entitled to. ${ }^{72}$ Significantly many of the 'bad' Roma are identified as being of Irish origin, who escaped to the UK in order not to comply with the caravan legislations there.

The Dale Farm story concerns a long-running legal debate over an Irish Traveller community's right to live in an encampment on land they had owned for 10 years but did not get planning permission to do so, as their site was seen as a threat to the surrounding community. The Guardian's coverage of the eviction was both nuanced, sympathetic in tone and included a range of different views including that of the travellers. Nevertheless it still deploys the racially objectifying discourses historically associated with the right wing press, primarily depicting Dale Farm as squalid. ${ }^{73}$ The Sun adopted a different representational strategy, depicting Dale Farm as a site of both undeserved privilege for the travellers that live there and as a drain on state resources. ${ }^{74}$

The Sheffield story focuses on the moral panic generated by David Blunkett's ${ }^{75}$ remarks which appeared to suggest that the worst imaginable outcome of the easing of migration to the UK from Romania and Bulgaria is the arrival en masse of Roma from these countries ${ }^{76}$. Discursive frameworks of law and welfare do not disappear entirely from this story but they are superseded by explicitly racialized discourses in both newspapers. 
The Guardian does this in a contradictory fashion. While it published an explicitly anti-racist feature, ${ }^{77}$ it also published an in-depth feature from the anti-Gypsyist perspective of a multi-ethnic vigilante group who police the streets of Sheffield. ${ }^{78}$ The effect is a peculiarly racialized construction of a super-diverse, yet still racist, British self, constructed against an homogenized, potentially criminal Roma migrant Other. The Sun reproduces the same discourses but includes even more crude racial stereotypes of the recent Roma migrants. They are 'filthy' ${ }^{79}$. They have 'reputation for industrial-scale begging and theft' ${ }^{80}$ They also attempt to sell babies to multicultural shop owners. ${ }^{81}$ Interestingly, unlike in previous years, The Guardian offers no space for Roma voices while the Sun does include a Roma voice in its coverage. ${ }^{82}$ This pattern repeats itself also in the 'blond Maria' story.

In the UK coverage of the 'blond Maria', discourses of biological constructions of race predominate almost entirely, focusing on hair colour and skin pigmentation..$^{83}$ In The Sun, crude representations of Roma portray them as fairy tale villains, swarthy child snatchers who force children to dance for money and enter into forced marriages. ${ }^{84}$ The Guardian's coverage is more nuanced and reflexive, running a range of different types of feature on the story, including an opinion piece by a self-identified blond Roma man. ${ }^{85}$ Despite the heavily racialized construction in both papers, they both also refer to how economically and racially discriminated Roma are, The Guardian more so than The Sun. ${ }^{86}$

In the main, then, The Guardian has tended to have more self-reflexive and multidimensional coverage than The Sun. However, throughout this historical period The Sun appeared to set the news agenda, with The Guardian often reacting to it and other right wing tabloids. At the beginning of the period The Guardian included more Roma voices in its coverage and was more sympathetic to their situations than The Sun. In 2013 The Guardian allows space for fewer Roma voices and produces more troublingly racialized representations of Roma. The Sun consistently produces cruder racial stereotypes of different Roma groups throughout.

During this period two clear trends of change develop in Roma representations across both newspapers. Firstly, different Roma groups are frequently constructed as a sign onto which anxieties re EU policies that are 
perceived as threatening Britain's sovereignty and territorial integrity are projected. Secondly, in the unfolding of this process, a multiplicity of discourses the general trend has been a move towards a racialized representation that assigns Roma groups a fixed inferior identity similar to the (post-)colonial representation of black and Asian people. As such, it is implied, they can never belong to British society.

\section{Concluding discussion}

This examination of discourses of both 'left' and 'right' main stream newspapers in Hungary, Finland and the UK has clearly shown that Roma people have been racialized and 'othered' in all three countries, although the historical specificity of each country means that these discourses are constructed around differing policies, practices and everyday borderings.

An essential part of these racialized discourses is the process of homogenization. Although in the UK and Hungary the 'indigenous' Roma belong to more than one cultural and linguistic group, these differences do not usually appear in the media narratives. While country of origin might be specified, in Finland and the UK, the two countries with migrant Roma, the only significant distinction made is between the local and the migrant Roma. This duality overlaps with a more or less subtle distinction made between the 'good' and the 'bad' (or 'accepted' and 'problematic') Roma, and works to reproduce racialized discourses on the alleged criminality of the latter.

The discourses on the Roma are caught in the basic ambivalence of the politics of belonging which are applied, in somewhat different ways in different countries, towards the local Roma. Even when constructed as part of the national citizenship body, they are consistently framed as being apart. The recognition of their 'otherness' operates both as a means of collective empowerment and self-representation and as means of exclusion, hierarchization and discrimination. In Hungary, we can see in the different case studies the effects of the shifts in policies and practices towards the Roma where, during the Soviet period, forced assimilation policies were enacted to obliterate ethnic distinctiveness and mobile livelihoods. The post-Soviet period saw the rise of self-representation and governance of Roma, but these policies of collective recognition were placed in a socio-economic context of 
rising unemployment, collapsing public housing and rising racialized violence that acted as a major factor pushing Hungarian Roma towards emigration as well as transnational travel to Western countries.

In Finland, the press discourses reveal racialisation of the immigrant Roma, who appear overwhelmingly as anonymous and problematic 'others'. Meanwhile, belonging and citizenship of the members of the national Roma minority are rarely questioned, and the press discourses towards them are characterised by an increasing sensitivity and even cautiousness. Still, they are persistently framed as ethnically distinctive 'special cases'.

Racialization and othering in the UK have been operating in different ways towards local and migrant Roma. The exclusionary discourses towards the former are often connected to anti-Gypsyist stereotypes of dangerous 'nomads'. Unlike in Hungary and Finland where post-war transformations forced Roma to find permanent housing, major sections of UK Roma continue to live in mobile homes. Although British multicultural policies have been aimed at migrants from the former empire, ${ }^{87}$ British traditions of patronage, acceptance of and provision for different ways of life were applied also towards the Roma, requiring local councils to provide official caravan sites where Roma could collectively live. This provision was never sufficient in space and often lacked appropriate amenities of education and health and with the neo-liberalization of the British state the legal space available to Roma became progressively more scarce. Much of the debates in the press, as in the Dale Farm case, focused on the criminalization of all those who could not or would not live on these sites, including those who managed to buy private land and wanted to live there on their own terms.

The similarities as well as differences in the construction of everyday borderings towards Roma in the three countries are expressed in the different extent to which they participate in the public media discourses concerning them. In Hungary, Roma voices are heard, but usually only those few who are considered the official representatives of the Roma community, especially around the period in which Hungary joined the EU and had to demonstrate a positive human rights record. ${ }^{88}$ In Finland, members of the national Roma minority frequently appear in texts concerning them; while the Roma migrants are continuously discussed but rarely heard. In the UK, there is less 
differentiation in this sense between local and migrant Roma but the ratio of their voices being allowed to be part of the media representation is the lowest of all.

An interesting difference between the ways Roma are racialized in the different countries came to light in the case study of the 'blond Maria' examined in the press of all three countries. In Hungary the Bulgarian Roma involved were constructed as Bulgarian seasonal workers. In Finland and even more so in the UK, the narratives of the press involved shift from a racialized culturalist construction of the Roma into a biological one.

Overall, our case studies from three highly divergent contexts make it clear that Roma are constructed as 'Others' in shifting and contested, yet highly persistent ways. While we found significant differences in discourses towards 'indigenous' Roma and migrant Roma, these differences go hand in hand with the general direction in which constructions of social and political borderings have been developing in Europe towards Roma in recent years which affect all Roma, migrant or not. These changes can be linked to more general changes in European politics of belonging, the rise of 'autochthonic' constructions of belonging (Yuval-Davis 2011) and the neo-liberalization of the relationships between civil society and the state.

The racialization and criminalization of Roma migrants serve, however, also another purpose. They have become a rhetoric and illustrative devise for those in western European countries, and particularly in Britain, who fear free movement of people within the expanded EU. The moral panics concerning migrant Roma, as described in the press of all three countries, are closely associated with the more general anxieties connected to westward mobilities from Central and East Europe (as well as from the global South). In Finland and the UK, the Roma are constructed as the most problematic or even dangerous of the Eastern European migrants. As a result, additional bordering practices concern the attempts of non-Roma migrants from these countries to differentiate themselves from the Roma so as not to be conflated with them. ${ }^{89}$ Most significantly, these migrations, as a result of the expansion of the EU and vital for its neo-liberal economy, have undermined the sense of closure and security of 'Fortress Europe' and reinforced xenophobic movements all over 
Europe that refuse to recognize EU citizens as entitled to national welfare provisions.

The most alarming - although not surprising - finding of our comparative study is that with time, the trajectories point towards increasing racialization and criminalization, with more exclusion and less collective recognition. The 2013 biological racialisation discourse of the 'blond Maria' case in Finland and the UK, unlike the more culturalist one used in most of the articles discussing the Roma during this period, is a sobering reminder that racialized discourses usually encompass, rather than simply substitute, earlier hegemonic ones.

\section{References}

Aluas, J. and Matei, L. 1998. Discrimination and prejudice: minorities in Romania. In Scapegoats and Social Actors: The Exclusion and Integration of Minorities in Western and Eastern Europe edited by Daniele Joly, 101-111. Basingstoke:Macmillan.Balch, A. and Balabanova, E. 2014. Ethics, Politics and Migration: Public Debates on the Free Movement of Romanians and Bulgarians in the UK, 2006-2013. Politics. DOI:10.1111/1467-9256.12082

Bernát, A. 2014. Leszakadóban: a romák társadalmi helyzete a mai Magyarországon. [Lagging behind: The Social Situation of Roma in the recent Hungary] In Társadalmi Riport edited by Kolosi T. and Tóth I. Gy. 246-264. Budapest: TÁRKI.

Bernáth G. and Messing V. 2013. Pushed to the Edge. Research Report on the Representation of Roma Communities in the Hungarian Mainstream Media, 2011. Budapest: CEU CPS

Brambilla, C. 2015. Exploring the critical potential of the borderscapes concept. Geopolitics 20 (1): 14-34.

Brown, P., Scullion L. and Martin, P. 2013. Migrant Roma in the United Kingdom: Population size and experiences of local authorities and partners, University of Salford.

http://www.salford.ac.uk/ data/assets/pdf file/0004/363118/Migrant Rom a in the UK final report October 2013.pdf Accessed 28 August 2015 Clark, C. and Campbell, E. 2000. 'Gypsy Invasion': a critical analysis of newspaper reaction to Czech and Romani asylum-seekers in Britain, 1997'. Romani Studies 5 10(1):23-27 
Edenborg, E. 2016. Nothing More to see: contestations of belonging and visibility in the Russian media. Lund and Malmo: Lund and Malmo Universities European Roma Rights Centre (ERRC) website. Accessed on 9 September 2015 at http://www.errc.org

Gramsci, A. 1971. Selections from The Prison Notebooks of Antonio Gramsci. Translated by Quintin Hoare and Geoffrey Nowell Smith. Reprint, London: Lawrence and Wishart, 2010.

Grill, J. 2012. Going up to England: Exploring Mobilities among Roma from Eastern Slovakia. Journal of Ethnic and Migration Studies, 38(8):1269-1287. Guild, E. and Carrera, S. 2013. International Relations, Citizenship and Minority Discrimination: Setting the Scene. In Foreigners, Refugees or Minorities? Rethinking People in the Context of Border Controls and Visas, edited by D. Bigo, S. Carrera, E. Guild. Farnham, England: Ashgate Publishing Limited. Izsák, R. 2015. Comprehensive study of the human rights situation of Roma worldwide, with a particular focus on the phenomenon of anti-Gypsyism Report to the Human Rights Council, June.

Kemény, I. (ed.) 2000. A magyarországi romák [Roma of Hungary]. Budapest: Press Publica.

Levine-Rasky, C., Beaudoin, J and St Clair, P. 2014. The exclusion of Roma claimants in Canadian Refugee Policy. Patterns of Prejudice. 48(1): 67-93. McCall, L. 2005. The Complexity of Intersectionality. Signs 30 (3): 1771-1800. Ministry of Social Affairs and Health 2009. The proposal of the working group for a national policy on Roma. Helsinki: Ministry of Social Affairs and Health. Picker, G. 2013. 'That neighbourhood is an ethnic bomb!': The emergence of an urban governance apparatus in Western Europe.' European Urban and Regional Studies 0(0) 1-13.

Rajaram, P.K. and C. Grundy-Warr, (eds) 2007. Borderscapes: Hidden Geographies and Politics at Territory's Edge. Minneapolis: University of Minnesota Press.

Ryder, A., Cemlyn, S. and Acton, T. (eds) 2014. Hearing the voices of Gypsy, Roma and Traveller communities. Inclusive Community Development. Bristol: Policy Press.

Sigona, N., and Trehan, N. (eds) 2009. Romani Politics in Contemporary Europe: Poverty, Ethnic Mobilization and Neoliberal Order. London: Palgrave Macmillan. 
Tanner, A. 2005. The Roma of Eastern Europe: still searching for inclusion, Migration Information Source (May).

www.migraitoninformation.org/feature/displace.cfm?id=308

Tervonen, M. 2012. Romanit ja suuri muutos' [Roma and the post-war transformation] in Suomen romanien historia. edited by Pulma, P, 166-197. Helsinki: Suomalaisen Kirjallisuuden Seura.

Vitale, T., and Legros, O. 2011 Les migrants roms dans les villes françaises et italiennes: mobilités, régulations et marginalités. [The migrant Roma in French and Italian cities: mobilities, regulation and marginality]. Géocarrefour, 86(1): 3-14.

Yuval-Davis, N. 2011. The Politics of Belonging: Intersectional Contestations. London: Sage.

Yuval-Davis, N. 2014. Situated Intersectionality and Social Inequality. Raisons Politiques 58: 91-100

Yuval-Davis, N., Cassidy, K. and Wemyss, G. 2017. (forthcoming). Bordering. Cambridge: Polity Press.

\footnotetext{
${ }^{1}$ While an estimate of 8-12 million Roma people in Europe is often cited (eg. Tanner 2005), other estimates vary between 4-14 million, pointing to a substantial uncertainty about the category (Guild and Carrera 2013, 47).

${ }^{2}$ As in the rest of the special issue we use the term Roma as a generic term while being aware of the multiple and contested labels in which the subject of the analysis in this article are named by themselves and by others.

${ }^{3}$ This distinction is rare, however, both in the media and in the scientific literature.

${ }^{4}$ We are using the term anti-gypsyism following the Special Report by R. Izsák (2015) for the Human Rights Commission.

${ }^{5}$ As is the case with all the largest newspapers in Finland, both Helsingin Sanomat and Iltalehti are politically independent and formally non-aligned.

${ }^{6}$ NSZ: 67 (38 news, 13 features, 1 letter, 15 op-ed)articles; MN: 19 (11 news, 3 op-ed, 5 features).

${ }^{7}$ NSZ: 73 (57 news, 10 op-ed, 6 features); MN: 60 (36 news, 7 features, 4 letters, 13 op-ed).

${ }^{8}$ NSZ: 126 (79 news, 27 features, 20 op-ed); MN: 72 (37 news, 2 letters, 14 features, 19 op-ed).
} 
${ }^{9} \mathrm{HS}: 148$ articles (82 news, 13 letters, 10 op-eds/editorials, 43 features). IL: 31 articles ( 21 news, 1 editorials, 4 letters, 5 features).

${ }^{10} \mathrm{HS}: 47$ articles (17 news, 9 op-eds/editorials, 11 letters, 10 features). IL: 6 articles (3 news, 1 letter, 1 editorial, 1 features).

${ }^{11}$ HS: 149 articles (77 news, 14 op-eds/editorials, 23 letters, 35 features). IL: 24 articles (19 news, 5 features).

${ }^{12}$ The Nexis database used to find these articles cannot return more than 3000 search results.

${ }^{13}$ The Guardian had 16 articles ( 10 news, 6 letters), The Sun 11 (7 news, 12 op-ed) .

${ }^{14}$ The Guardian-24 (14 news, 1 letter, 7 op-ed, 2 features) The Sun -64 articles (47 news, 4 letters, 12 op-ed)

${ }^{15}$ The Guardian -50 articles ( 33 news, 4 letters, 8 op-ed, 5 features). The Sun - 111 (90 news, 16 op-ed, 5 features).

${ }^{16}$ The Guardian -11 articles (6 news, 5 op-ed). The Sun - 13 (9 news, 4 op-ed).

${ }^{17}$ The articles which appeared in October 2013 relating to the 'blond Maria' story in the newspapers we studies in the three countries were: Hungary- no articles in MN; 3 in NSZ.

Finland: 13 in $I L$ and 7 in HS. The UK: 12 in The Guardian (8 news, 4 op-ed); 23 in The Sun (22 news, 1 op-ed).

${ }^{18}$ E.g. Roma from Mohács (and often from Miskolc) who often migrated to Canada, were identified as

'Canadian' Roma.

${ }^{19}$ Village in Hungary.

20 'National Roma Government' was organised as an NGO, representing Roma on national level, the 'official' partner of the government in Roma issues.

${ }^{21}$ MN: 'Obsession of 'Fehérvár'; NSZ: 'Radio street: the story of a compromise'. November 29, 1997

${ }^{22}$ It was established In February 1989, in Miskolc and is seen as 'the starting point of Roma self-organisation Roma civil right movement' (NSZ,Februray 21, 2009)

${ }^{23}$ E.g.:' $\ldots$..the behaviour of the leader of local minority government is very close to corruption...István Hell, József Krasznai ...and Aladár Horváth (Roma representatives) tried to make political capital unfairly in the period of election.' (by another former Roma representative:MN, January 10, 1998).

24 Cf. Bernáth and Messing 2013

${ }^{25}$ e.g. 'They came back' MN, May 15, 2009

${ }^{26}$ e.g. 'Asylum seeking' NSZ, June 8, 2009

${ }^{27}$ NSZ, short articles on the 22,23,25\&26th of October, 2013

${ }^{28}$ e.g. 'French refugee status for Zámolyans' NSZ, January 6, 2001 'Two politicians from the opposition (leftwing, MSZP) went to Strasbourg to meet with Roma migrants and discuss their main problems (to make political benefit from the situation).'NSZ, March 14, 2001; 'We should see how this campaign was organised: these people departed from a small village and arrived into the middle of the EU. It would be worth to ask: Who paid for the whole action?' MN, January 10, 2001

${ }^{29}$ The word 'mustalainen' practically disappears in HS but appears occasionally in IL; e.g. in a story published 27 October 1999, IL refers to Romani culture throughout, but concludes that there are approximately 10,000 'mustalaista' in Finland.

${ }^{30}$ Yet, individual articles particularly in the IL portray Roma 'cultural rules' as a source of problems, alleged to cause difficulties in allocating public housing ${ }^{30}$, family feuds and discrimination against women, for example. IL August 25,2007; IL, January 10,2009

${ }^{31}$ E.g. IL, July 2,1999; IL, July 5,1999; HS, June 30, 1999

${ }^{32}$ IL, July 5,1999

${ }^{33}$ E.g referring to the flights taken by the asylum seekers as 'wandering' or 'nomadism' (vaellus) Romanien kansainvaellus, IL, July 5, 1999; or, to childlike migrants with 'dark eyes' and to the Emil Kusturica movie Queen of the Gypsies; (IL, June 30, 1999).

${ }^{34}$ Cf. IL July 7, 1999; HS, July 7, 1999.

${ }^{35}$ Citation from HS July 7, 1999; compare to the article on the same day in $I L$.

${ }^{36}$ The two newspaper use strikingly similar rhetoric derived from the authorities. According to the IL, "The world's refugee problem is not solved by opening the borders of Finland; and it is doubtable whether those in the biggest need of help ever even appear on our airports" (IL, July 5, 1999). Meanwhile, HS claims the "Law has to be changed quickly" and that "The loopholes in the present law do not serve anyone's interests, least of all of those in genuine need for an asylum. The welfare refugees enabled by the present law only stoke xenophobia" (HS, July7 1999).

${ }^{37}$ IL, July 7, 1999; HS, July 7,1999

${ }^{38}$ IL, July7, 1999

${ }^{39}$ E.g. HS December 7, 2009; IL July 9,2013. 
${ }^{40}$ E.g. IL, June 20,2011; HS, March 22, 2008.

${ }^{41}$ An early example of this dominant narrative in HS is a story titled "The Roma are victims above all " (HS, January 14, 2008).

42 IL, July 9,2013.

${ }^{43}$ HS, August 20, 2010

${ }^{44}$ As stated by an MP interviewed by HS, December 21, 2010. Besides discrimination, a victim-perspective is evident in articles which consider the arrival of first the asylum seekers and later EU-migrants as a result of a hoax by organized criminals, who 'tricked the Roma in order to make money'. Eg. IL, July 8, 1999; HS,

November 27, 2009.

${ }^{45}$ E.g. IL, March 18, 2014; HS, March 8, 2014.

${ }^{46}$ E.g. HS, September 4, 2014.

${ }^{47}$ E.g. HS May 24, 2014.

48 E.g. 'Roma problem' solved by Visa restriction (IL, July 7, 1999); 'Roma problem' requires European efforts (HS, October 12, 2010).

49 IL, June 20, 2011.

${ }^{50}$ E.g. HS, March 22, 2008.

${ }^{51}$ On October 19, IL shifted focus to Maria's neglected state, praising the 'safe children's home' she's was admitted into. While the conditions provided by her host parents are described as "crammed and unhygienic", no worry is expressed for the children remaining in these conditions who were not blonde and blue-eyed. $I L$, October 18, 19, 22,24, 25 \& 26, 2013.

52 The same was true of the two subsequent Irish cases: the focus was on ethnicity rather than on poverty or child welfare. In contrast to national reporting, HS and IL refered to "the Roma", whether the context was Ireland, Greece or Bulgaria.

${ }^{53}$ E.g. HS, January 6, 2000

${ }^{54}$ The Sun, October 21,1997; The Sun, October 24, 1997; The Guardian October 22, 1997.

${ }^{55} 22$ October 1997.

${ }^{56} 22$ October 1997.

${ }^{57} 28$ October 1997.

${ }^{58} 22$ October 1997; 25 October 1997.

5913 November 1997.

60 'Yes, we're noisier and more temperamental, but that's the way we were born. When I celebrate my birthday, I like to drink and sing, but the Czechs find that hard to deal with.' Arnost Kotlar, roma. (ref)

${ }^{61} 23$ October 1997

62 230ctober 2005

6317 March2005.

${ }^{64}$ The Sun, March 21,2005

${ }^{65}$ The Sun, March 22, 2005

${ }^{66}$ The Sun, March 10, 2005.

${ }^{67} 21$ March 2005

6814 March 2005

${ }^{69} 11$ March 2005

7019 March 2005.

7111 March 2005

7214 March 2005

73 'On an island of gravel surrounded by a sea of mud, Michelle Sheridan closes her caravan door against the stench of raw sewage and makes a cup of tea.' (4 November).

${ }^{74} 26$ September 2011.

${ }^{75}$ A former Labour government minister

${ }^{76}$ Race row boiling in borderless Britain; LABOUR WARNS OF TENSION..."(17 November 2013 - 28 and 29)

7718 November 2013

7816 November 2013

7917 November 2013

8030 December 2013

${ }^{81} 15$ November 2013

8217 November 2013

${ }^{83}$ The Sun, October 23, 2013; The Guardian, October 212013 
${ }^{84} 22$ October 2013; 24 October 2013

${ }^{85} 26$ October 2013

${ }^{86}$ The Guardian, October 22-25, 2013; The Sun, October 24, 2013.

${ }^{87}$ what used to be known as NCWP countries

${ }^{88}$ For ways in which these formal voices have been challenged please see the article by Scott et al. in this issue.

${ }^{89}$ See the paper by Cassidy and Wemyss in this issue. 